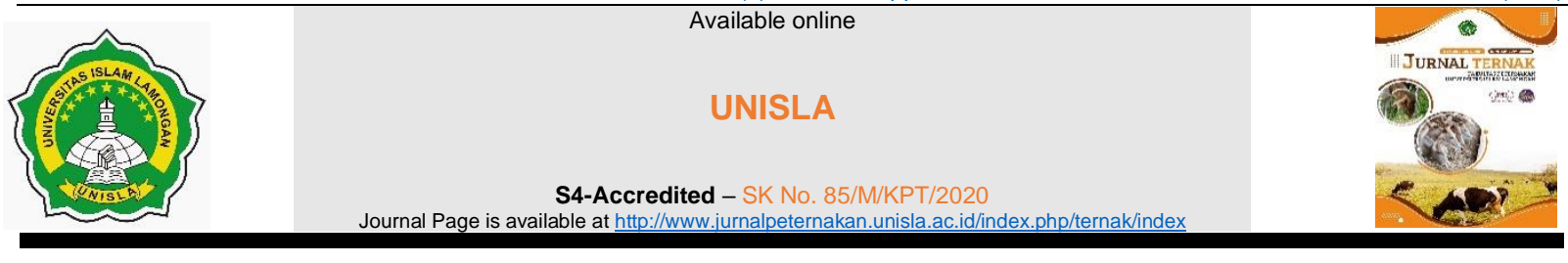

\title{
The Supplementation of Urea Molasses Multi-nutrient Moringa Block (UM3B) on the Diameter and Total Follicle in Balinese Cows
}

\author{
Abdul Malika", Siti Erlina ${ }^{b}$, Aam Gunawanc, Neni Widianingsihd , Rizki Elvaniae, Mawardif \\ $a^{*}, b, c, d, e$ Faculty of Animal Science, Universitas Islam Kalimantan Muhammad Arsyad Al - Banjari, Banjarmasin, Indonesia \\ f Department of Animal Science of Tanah laut Regency, South Borneo, 70815 \\ email: sidol_99@yahoo.co.id
}

\begin{tabular}{l}
\hline A R T I C L E I N F O \\
\hline Article history: \\
Received 22 December 2020 \\
Revised 5 January 2021 \\
Accepted 2 Juny 2021 \\
Available online 7 Juny 2021 \\
\hline
\end{tabular}

Keywords:

UM3B,

Bali Cows,

Diameter of Follicle

Total of Follicle

\section{A B S T R A C T}

The research of the aim to analyze giving of urea molasses multi-nutrient moringa block (UM3B) to the amount and diameter of follicles in crossbred cattle. A total of 10 cows were used study. all cows were divided two groups, one group consist of 5 crossbreed cows. Group one was given UM3B, and group two was not given UM3B (control). The result of this study about total of follicle was significant different $(\mathrm{P}>0,05)$ between group one (with $\mathrm{UM} 3 \mathrm{~B})$ and group two (control) without UM3B, whereas, the diameters of the follicles was no significant different $(\mathrm{P}<0,05)$ among group one with $\mathrm{UM} 3 \mathrm{~B}$ and group two without UM3B, but trend of diameter of follicle show batter with group one. The conclusion of study was the use of urea molasses multi-nutrient moringa block (UM3B) giving a positive impact on total of follicular growth in the right and left ovary.

\footnotetext{
IEEE style in citing this article:

A.Malik, S. Erlina, A. Gunawan, N. Widianingsih, R. Elvania, Mawardi" The Supplementation of Urea Molasses Multi-nutrient Moringa Block (UM3B) on the Diameter and Total Follicle in Balinese Cows " Jurnal Ternak Universitas Islam Lamongan, vol. 12, no. 01 , pp., $11-15$.
}

\section{Introduction}

One of the factors that influence the success of beef cattle farming is the availability of good feed. The phenomenon of green availability in tropical countries such as Indonesia is a challenge because there are two long seasons, the dry and the rainy. During the rainy season, forage sources are abundant in both quantity and quality, while the dry season forage availability is the opposite. The feed supplement that has been known and circulated so far is Urea Molasses Block (UMB). UMB was later developed by adding better multi-nutrients, becaming Urea Molasses Multi-nutrient Block (UMMB). The development continued by researching for better quality feed ingredients in order to increase the quality of UMMB. One of the legumes that contain high nutrients is Moringa (Moringa Oliveera). In order to increase the nutritional value of $\mathrm{UMMB}$, the addition of Moringa leaves is a good choice, considering that Moringa is an ingredient that contains complete nutrition for animal feed [2]. The addition of Moringa in UMMB becomes Urea Molasses Multi-nutrient Moringa Block (UM3B). 
Furthermore, [3] reported that the addition of UM3B supplement had an effect on the consumption and digestibility of Balinese cattle.

The addition of Moringa leaves in urea molasses multi-nutrient block (UMMB) is expected to increase the productivity and reproducibility of beef cattle as they have complete nutritional content. The results of the study [4] showed that Moringa leaf flour can be used as a feed supplement for ruminants. This is in line with the result reported by [5] that Moringa leaf flour contains complete nutrients such as protein, vitamins and minerals. Based on this description, this research was conducted with a focus on the effect of giving Moringa Block (UM3B) Multi-nutrient Urea Molasses (UM3B) on the estrus cycle, especially on the average total number of follicles and the average diameter of the ovarian follicles of beef cattle.

\section{Method}

This research was conducted in Farmer Group of Rukun Makmur, Kunyit Village, Bajuin District, Tanah Laut Regency. The subject of this study were 10 female Balinese cattle aged between 4-6 years, not pregnant. The first group was treatment, comprised of 5 cows that were given additional feed treatment of Urea Molasses Multi-nutrient Moringa Block (UM3B) as much as $350 \mathrm{~g} /$ head / day for 40 days. The second group was control, consisted of 5 cows that were not given UM3B. The composition/formulation and nutritional content of UM3B were adopted from [3]. The basic feed given to all livestock was in the form of forage feed from field grass and elephant grass feed of about $10 \%$ of body weight, additional feed in the form of bran $1 \mathrm{~kg} / \mathrm{head} / \mathrm{day}$. The parameters observed in this study were the average diameter of the follicles and the average total number of follicles in the ovaries of each cow in each group. The tool used to detect the diameter and number of follicles in the ovaries is an Ultrasonography (USG) scan with the trademark of Mindray DP 10 (Shenzhen Mindray Bio-medical Electro I.Cs co.LTD)

The assessment of the follicles on the right or left ovaries was done by rectal palpation utilizing Ultrasonography (USG) scan and ultrasound diagnostic probe from Mindray. The observation of the number and diameter of follicles started on day 3 since UM3B administration and was carried out every 2 days for 30 days. The variables observed in the study were the number and diameter of the follicles. The data obtained then analyzed using the $t$ test.

\section{Results and Discussion}

The results of the observation on the number of follicles in the ovaries of cows both in the control and treatment groups are presented in Figure 1. The data shows that the administration of UM3B in the treatment group in each observation the number of follicles in the group significantly increased compared to the control group, except for the first observation. Meanwhile, based on the results of statistical analysis, there was a significant difference $(P<0.05)$ between the control group (without $\mathrm{UM} 3 \mathrm{~B}$ ) and treatment group. In the group of cows that were given UM3B, there was a trend of developing more follicles compared to the the control group.

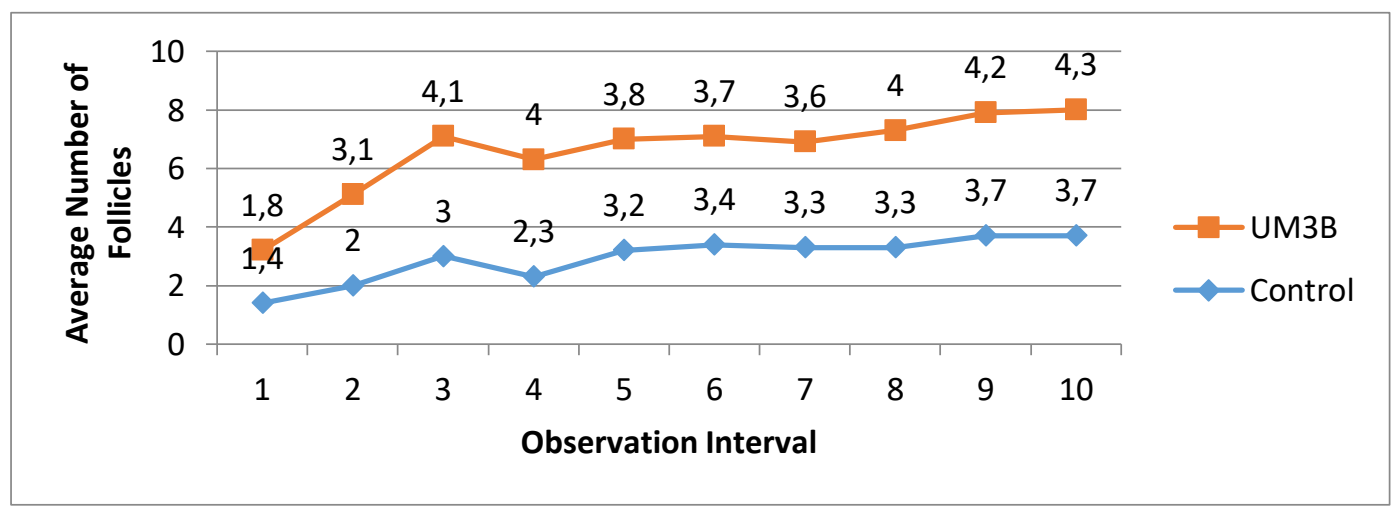


Figure 1. The average number of follicles on each observation interval of treatment group (UM3B) and control group

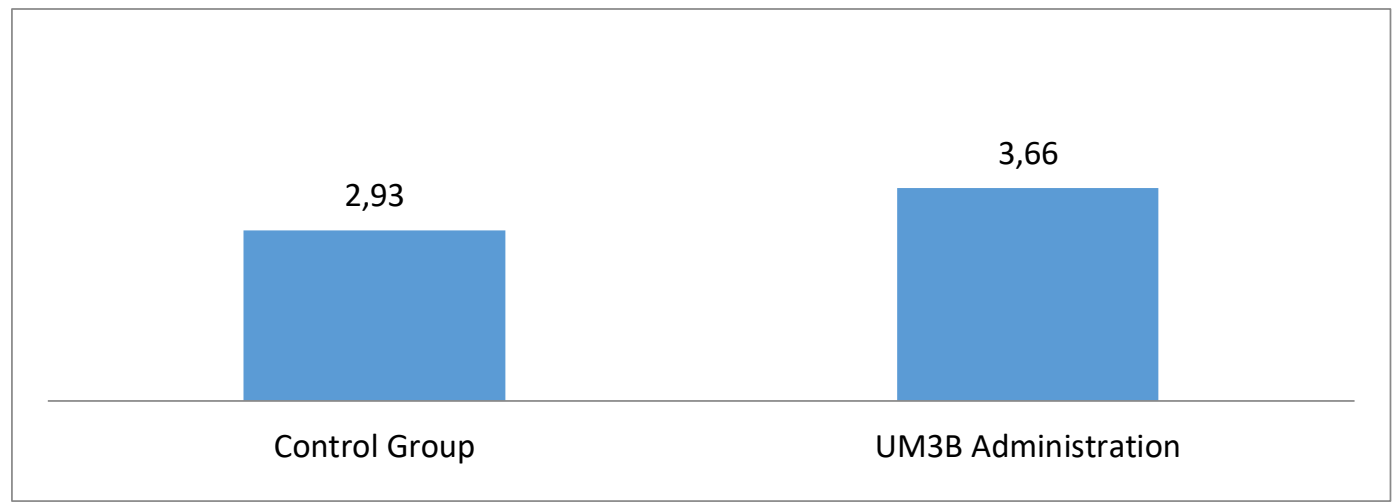

Figure 2. The average number of follicles between control group and treatment group

This is presumably due to the UM3B administration in the treatment group. UM3B which contains a complete nutritional composition had a positive impact on the reproductive activity of female cattle which was characterized by an increase in the growth of follicles in the ovaries. This result is supported by [6] stating that the development of reproductive organs was highly dependent on the ability of endocrine function to produce reproductive hormones, which must be balanced with the availability of good nutrition. Meanwhile, [7] stated that the effect of nutrition directly affected GnRH in the hypothalamus or gonadotrophin secretion in the pituitary. This result is reinforced as well by [8] and [9] that stated the livestock that is fed with adequate energy and protein intake causes the livestock to grow quickly and show symptoms of normal estrus.

The administration of UM3B whose main component contains Moringa leaves showed an increase in the number of follicles in the ovaries of cows in each treatment group. This is because Moringa contains complete crude protein, energy, vitamins, and minerals that has positive impact on the reproductive cycle [10]. Furthermore, [1] stated that beef cattle which experienced a decrease in food levels generally slowed the development of the number of follicles, whereas, high levels of food could accelerate the development of follicle numbers. Lack of food indirectly affects hormone function and causes reproductive disorders which are characterized by imperfect reproductive organs and undeveloped follicles so that they do not show symptoms of estrus or silent heat. [11] added that the level of food affects the synthesis and release of hormones from the endocrine glands, so that the nutritional status of cattle affects follicular development and ovulatory capacity.

The results of observations of the diameter of the dominant follicle in the ovary in the control and treatment groups can be seen in Table 1. The data showed that the administration of UM3B in the treatment group in each observation manifested an increase in the diameter of the dominant follicle compared to the control group. Meanwhile, the statistical analysis showed that there was a significant difference in follicle diameter $(\mathrm{P}<0.05)$ between the control group (without $\mathrm{UM} 3 \mathrm{~B}$ ) and the treatment group with UM3B (figure 4). In the group of cows that were given UM3B, there was a trend of developing more follicles compared to the the control group. 
Table 1. The dominant follicle diameter on treatment group and control group

\begin{tabular}{llccccccccc}
\hline & \multicolumn{8}{c}{ The dominant follicle diamaeter in treatment group and control group based } \\
& \multicolumn{1}{c}{ on the observation interval $(\mathrm{mm})$} \\
& $\mathbf{1}$ & $\mathbf{2}$ & $\mathbf{3}$ & $\mathbf{4}$ & $\mathbf{5}$ & $\mathbf{6}$ & $\mathbf{7}$ & $\mathbf{8}$ & $\mathbf{9}$ & $\mathbf{1 0}$ \\
\hline $\begin{array}{l}\text { Treatment with } \\
\text { UM3B(n=5) }\end{array}$ & 15,5 & 14,25 & 13,25 & 13,5 & 14,0 & 15,6 & 13,6 & 14,25 & 13,5 & 15,6 \\
$\begin{array}{l}\text { Control without } \\
\text { UM3B(n=5) }\end{array}$ & 13,2 & 13,5 & 12,6 & 11,0 & 12,8 & 13,8 & 12,4 & 11,25 & 12,5 & 13,0 \\
\hline
\end{tabular}

The classification of ovaries varies according to species, age, and reproductive status of the structures within them [12]. The ovary is oval in shape and varies in length and width and according to the structure it contains [1]. he results showed that there was a difference in activity between the ovaries that were given UM3B and ovaries that were not given UM3B. The follicular development of the ovary has different activities that give different numbers and morphology of follicles. [13] explained that the characteristics of the ovary are also influenced by existing structures such as the presence of follicles and corpus leteum. Furthermore, ovaries that given UM3B tend to produce better follicle diameter. This is in accordance with [12] stating that physiologically, the ovaries that are given a balanced nutrition, has more blood flow. Thus, better follicular development is possible, especially in diameter, which is associated with an increase in follicle size.

In this study, the results showed that the observed diameters had stable follicle diameters when given $\mathrm{UM} 3 \mathrm{~B}$ compared to bovine follicles that were not given UM3B, there was a difference in both the size and development of the follicles. The cows that given UM3B had rapid follicular development, so that they showed signs of lust more quickly. The content of Moringa leaves contained in UM3B has a significant effect on the development of follicles, especially in the diameter. The complete nutritional content of Moringa leaves turns out to be able to improve the function and metabolism of cells and important hormones that play an active role in reproductive performance. All hormones are unique and selective in their effect on genetically determined target organs. The target organ immediately reacts to a certain hormone to produce substances or genetically programmed changes [11].

On the other hand, the supplementation of UM3B in the treatment group giving additional nutrients that were beneficial for the cattles, resulting in the follicles increasing number. The additional nutrients containing, urea, mollage, multi nutrient, and Moringa completed the nutrients to meet nutrient deficiencies in basal feed, This statement is supported by [14] and [15] who reported that many researchers state that energy deficits are the reason for the emergence of functional disorders of the reproductive system, such as long-term ovarian dysfunction or delay in the onset of normal ovarian activity.

\section{Conclusion}

The administration of Urea Molasses Multi-nutrient Block (UM3B) supplementation in cattle had a positive impact on the development of the number of follicles and the diameter of the follicles in the ovaries of Balinese cattle. 


\section{References}

[1] M. R. Toelihere, "Fisiologi Reproduksi pada Ternak. penerbit Angkasa.” Bandung, 1993.

[2] A. T. A. Baptista, M. O. Silva, R. G. Gomes, R. Bergamasco, M. F. Vieira, dan A. M. S. Vieira, "Protein fractionation of seeds of Moringa oleifera lam and its application in superficial water treatment," Sep. Purif. Technol., vol. 180, hal. 114-124, 2017.

[3] A. Malik, A. Gunawan, S. Erlina, dan R. E. Widaningsih, "Effect of moringa oleifera (moringa) supplementation via urea molasses multi-nutrient moringa block (um3b) on nutrient intake and utilization in bali cattle," J. Anim. Heal. Prod, vol. 7, no. 2, hal. 70-74, 2019.

[4] J. K. Murro, V. R. M. Muhikambele, dan S. V Sarwatt, "Moringa oleifera leaf meal can replace cottonseed cake in the concentrate mix fed with Rhodes grass (Chloris gayana) hay for growing sheep," Livest. Res. Rural Dev., vol. 15, no. 11, hal. 1-4, 2003.

[5] N. M. Witariadi, I. K. M. Budiasa, E. Puspani, dan I. Cakra, "Pengaruh tepung daun gamal dan daun kelor dalam urea cassava blok (UCB) terhadap kecernaan, kadar VFA, dan NH3 in-vitro," Maj. Ilm. Peternak., vol. 13, no. 1, hal. 164175, 2015.

[6] Y. Yendraliza, "Pengaruh Nutrisi dalam Pengelolaan Reproduksi Ternak (Studi Literatur)," Kutubkhanah, vol. 16, no. 1, hal. 20-26, 2013.

[7] M. G. Diskin, D. R. Mackey, J. F. Roche, dan J. M. Sreenan, "Effects of nutrition and metabolic status on circulating hormones and ovarian follicle development in cattle," Anim. Reprod. Sci., vol. 78, no. 3-4, hal. $345-370,2003$

[8] C.-H. SON, H.-G. KANG, dan S.-H. KIM, "Application of progesterone measurement for age and body weight at puberty, and postpartum anestrus in Korean native cattle," J. Vet. Med. Sci., vol. 63, no. 12, hal. 1287-1291, 2001

[9] M. A. Romano, W. H. Barnabe, A. E. D. Feliciano, A. R. de Freitas, dan R. M. Romano, "The effect of nutritional level on advancing age at puberty in Nelore heifers," Ambiência, vol. 1, no. 1, hal. 157-167, 2005 .

[10] J. K. Raman, C. M. Alves, dan E. Gnansounou, "A review on moringa tree and vetiver grass-Potential biorefinery feedstocks,” Bioresour. Technol., vol. 249, hal. 1044-1051, 2018.

[11] M. P. Feradis, "Bioteknologi Reproduksi Pada Ternak,” Alf. Bandung, 2010.

[12] S. Hardjopranjoto, "Ilmu kemajiran pada ternak.” Airlangga University Press. Surabaya, 1995.

[13] J. Hendri, Hendri, Zaitun, U, Bioteknologi Reproduksi Ternak. Fakultas Peternakan - Universitas Andalas, 2004.

[14] S. Llewellyn, R. Fitzpatrick, D. A. Kenny, J. J. Murphy, R. J. Scaramuzzi, dan D. C. Wathes, "Effect of negative energy balance on the insulin-like growth factor system in pre-recruitment ovarian follicles of post partum dairy cows," Reproduction, vol. 133, no. 3, hal. 627-639, 2007.

[15] V. C. Zulu, Y. Sawamukai, K. Nakada, K. Kida, dan M. Moriyoshi, "Relationship among insulin-like growth factor-I, blood metabolites and postpartum ovarian function in dairy cows," J. Vet. Med. Sci., vol. 64, no. 10, hal. 879-885, 2002. 